\title{
Climate Change and Invasibility of the Antarctic Benthos
}

\section{Richard B. Aronson, ${ }^{1}$ Sven Thatje, ${ }^{2}$ Andrew Clarke, ${ }^{3}$ Lloyd S. Peck, ${ }^{3}$ Daniel B. Blake, ${ }^{4}$ Cheryl D. Wilga, ${ }^{5}$ and Brad A. Seibel ${ }^{5}$}

\footnotetext{
${ }^{1}$ Dauphin Island Sea Lab, Dauphin Island, Alabama 36528; email: raronson@disl.org

${ }^{2}$ National Oceanography Centre, Southampton, School of Ocean and Earth Science, University of Southampton, Southampton SO14 3ZH, United Kingdom; email: svth@noc.soton.ac.uk

${ }^{3}$ British Antarctic Survey, NERC, Cambridge CB3 0ET, United Kingdom; email: andrew.clarke@bas.c.uk, l.peck@bas.ac.uk

${ }^{4}$ Department of Geology, University of Illinois, Urbana, Illinois 61801; email: dblake@uiuc.edu

${ }^{5}$ Department of Biological Sciences, University of Rhode Island, Kingston, Rhode Island 02881; email: cwilga@uri.edu, seibel@uri.edu
}

Annu. Rev. Ecol. Evol. Syst. 2007. 38:129-54

The Annual Review of Ecology, Evolution, and Systematics is online at http://ecolsys.annualreviews.org

This article's doi: 10.1146/annurev.ecolsys.38.091206.095525

Copyright (c) 2007 by Annual Reviews. All rights reserved

$1543-592 X / 07 / 1201-0129 \$ 20.00$

\section{Key Words}

climate change, Decapoda, invasive species, physiology, polar, predation
Abstract
Benthic communities living in shallow-shelf habitats in Antarctica $(<100-\mathrm{m} \mathrm{depth})$ are archaic in structure and function compared to shallow-water communities elsewhere. Modern predators, includ- ing fast-moving, durophagous (skeleton-crushing) bony fish, sharks, and crabs, are rare or absent; slow-moving invertebrates are gener- ally the top predators; and epifaunal suspension feeders dominate many soft-substratum communities. Cooling temperatures begin- ning in the late Eocene excluded durophagous predators, ultimately resulting in the endemic living fauna and its unique food-web struc- ture. Although the Southern Ocean is oceanographically isolated, the barriers to biological invasion are primarily physiological rather than geographic. Cold temperatures impose limits to performance that exclude modern predators. Global warming is now removing those physiological barriers, and crabs are reinvading Antarctica. As sea temperatures continue to rise, the invasion of durophagous predators will modernize the shelf benthos and erode the indigenous character of marine life in Antarctica. 


\section{INTRODUCTION}

Global climate change is altering the geographic ranges, behaviors, and phenologies of terrestrial, freshwater, and marine species. A warming climate, therefore, appears destined to change the composition and function of marine communities in ways that are complex and not entirely predictable (Clarke et al. 2007, Fields et al. 1993, Helmuth et al. 2006, Smetacek \& Nicol 2005, Walther et al. 2002). Higher temperatures are expected to increase the introduction and establishment of exotic species, thereby changing trophic relationships and homogenizing biotas (Stachowitz et al. 2002). Because organisms in polar regions are adapted to the coldest temperatures and most intense seasonality of resource supply on Earth (Peck et al. 2006), polar species and the communities they comprise are especially at risk from global warming and the concomitant invasion of species from lower latitudes (Aronson \& Blake 2001, Barnes et al. 2006, Thatje et al. 2005).

Shallow-water, benthic communities in Antarctica $(<100-\mathrm{m}$ depth) are unique. Nowhere else do giant pycnogonids, nemerteans, and isopods occur in shallow marine environments, cohabiting with fish that have antifreeze glycoproteins in their blood. An emphasis on brooding and lecithotrophic reproductive strategies (Pearse et al. 1991, Thorson 1950) and a trend toward gigantism (Chapelle \& Peck 1999, Peck 2002) are among the unusual features of the invertebrate fauna. Ecological and evolutionary responses to cold temperature underlie these peculiarities, making the Antarctic bottom fauna particularly vulnerable to climate change. The Antarctic benthos, living at the lower thermal limit to marine life, serves as a natural laboratory for understanding the impacts of climate change on marine systems in general.

Recent advances in the physiology, ecology, and evolutionary paleobiology of marine life in Antarctica make it possible to predict the nature of biological invasions facilitated by global warming and the likely responses of benthic communities to such invasions. This review draws on paleontology, biogeography, oceanography, physiology, molecular ecology, and community ecology. We explore the climatically driven origin of the peculiar community structure of modern benthic communities in Antarctica and the macroecological consequences of present and future global warming.

\section{THE MODERN FAUNA}

\section{The Southern Ocean}

The Southern Ocean comprises all waters south of the Polar Front, a well-defined circum-Antarctic oceanographic feature that marks the northernmost extent of cold surface water. The total area of the Southern Ocean is about 34.8 million $\mathrm{km}^{2}$, of which up to 21 million $\mathrm{km}^{2}$ are covered by ice at the winter maximum and about 7 million $\mathrm{km}^{2}$ are covered at the summer minimum (Zwally et al. 2002).

Much of the Southern Ocean overlies deep seafloor, the fauna of which is in general poorly known (Brandt et al. 2007). The continental shelf around Antarctica is unusually deep, partly from isostatic depression from the enormous mass of continental ice, 
but predominantly as a result of ice scour during previous extensions of the ice sheet (Anderson 1999, Huybrechts 2002). Continental shelves elsewhere in the world are typically 100-200 m deep and $75 \mathrm{~km}$ wide (Walsh 1988). Around Antarctica the shelf edges are closer inshore. They average over $450 \mathrm{~m}$ deep, and in places they extend to more than $1000-\mathrm{m}$ depth. Conventionally the $1000-\mathrm{m}$ isobath is taken to mark the edge of the Antarctic continental shelf (Clarke \& Johnston 2003), and the 3000-m isobath is taken as the transition from the continental slope to the continental rise (Snelgrove 2001).

\section{Benthos of the Southern Ocean}

The total species list for the Southern Ocean benthos currently exceeds 4100 (Clarke \& Johnston 2003). Gutt et al. (2004) estimated that the total macrofaunal diversity of the Southern Ocean continental shelf could exceed 15,000, meaning that most of the fauna remains undescribed.

Most noteworthy in terms of high species richness are the pycnogonids and ascidians. Polychaetes are also diverse, but that is not surprising because they are speciose almost everywhere else as well. For a number of taxa, low species richness in the Southern Ocean is not typical of that group in warmer waters; examples include gastropods, bivalves, decapods, and teleosts, all of which are highly speciose in many oceans but poorly represented in the Southern Ocean. Amphipods and isopods are well represented, although they are not particularly diverse. Some amphipod and isopod lineages radiated in the Southern Ocean (Brandt 1992, 2000; Held 2000; Watling \& Thurston 1989).

Antarctica contains $\sim 11 \%$ of the world's continental-shelf area. With the caveat that the Antarctic shelf is configured differently from continental shelves elsewhere in the world, we can calculate the fraction of the world's continental-shelf fauna found in Antarctica for each group (Figure 1). We see that none of the taxa there achieve levels of representation greater than about $15 \%$ in the Southern Ocean, and most are well below. The data do, however, reinforce the conclusion that polychaetes, bryozoans, sponges, pycnogonids, amphipods, and ascidians are well-represented in the Southern Ocean benthic fauna, whereas gastropods and bivalves in particular are not.

\section{Deep-Sea Affinities}

Many researchers have commented on the similarities between the fauna of the Antarctic continental shelf and typical deep-sea (bathyal to abyssal) communities. Two aspects in particular have attracted attention. The first is the importance of echinoderms in the fauna, and the second is the evolutionary connection between the faunas of the Antarctic continental shelf and the adjacent deep sea.

The unusual depth of the Antarctic continental shelf means that many taxa, elsewhere considered to be typical of shallow shelves, are living at depths traditionally regarded as bathyal. On the deeper parts of the Southern Ocean shelves, organisms require physiological adaptations to pressure that parallel those found in truly deep-sea
Decapods: crabs, hermit crabs, lobsters, shrimp, and related crustaceans

Teleosts: modern bony fish 


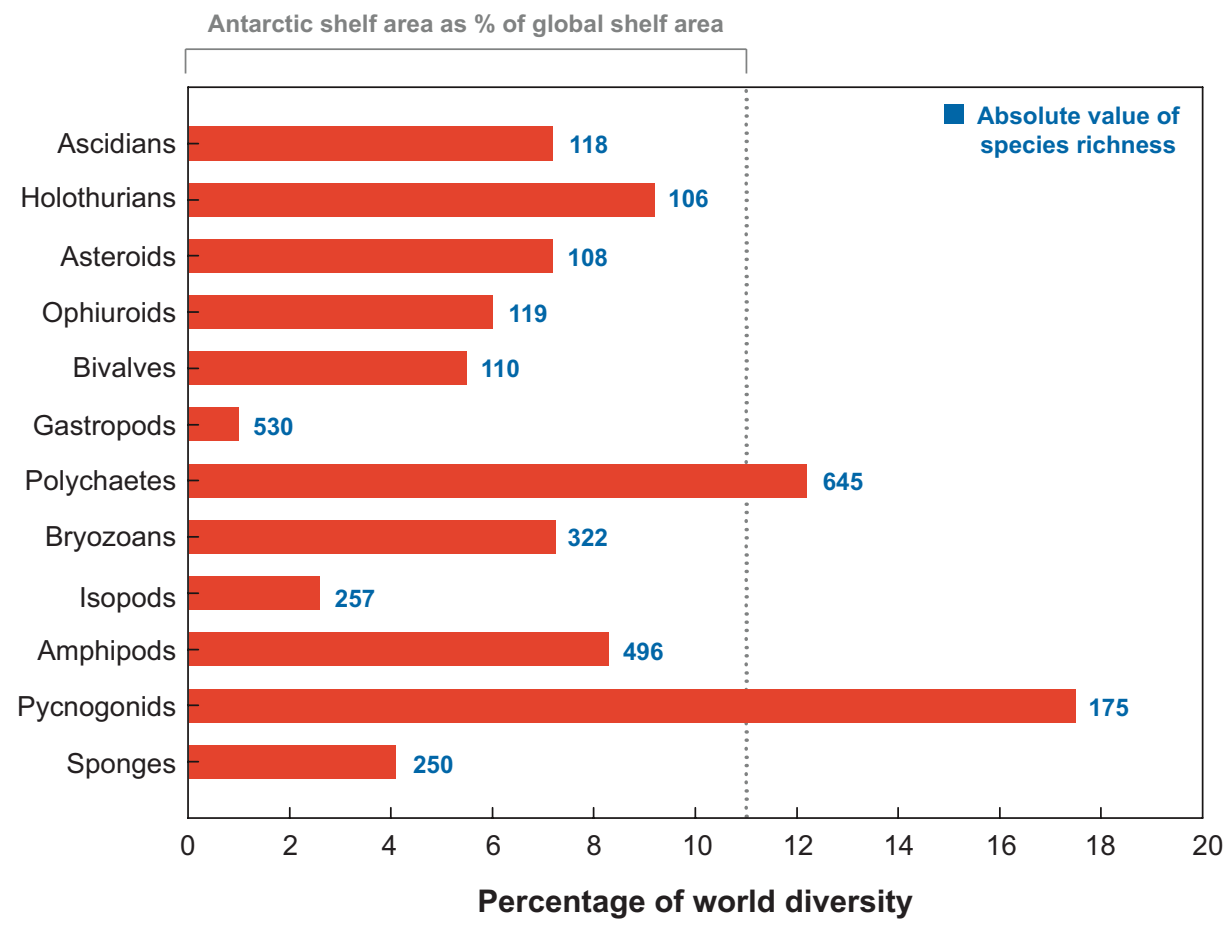

Figure 1

The most speciose taxa of benthic invertebrates in Antarctica (species richness of more than 100), shown as percentages of the worldwide species diversities of those taxa (bars) and absolute values of species richness (adjacent numbers). Colloquial names are used because the groups represent different taxonomic levels (phylum, class, or order). Vertical dotted line shows the area of the Antarctic continental shelf as a percentage of the total, worldwide continental-shelf area. Benthic hydrozoans are omitted because, although there are 186 species known from Antarctica, no reliable data exist for worldwide species richness. Values are from Clarke \& Johnston (2003).

organisms in other oceans (Clarke 2003). Echinoderms are an important component of the Antarctic shelf fauna, as they are in the deep sea (Gage \& Tyler 1991). The importance of echinoderms within the benthic fauna of the Antarctic shelf, and in particular the notable diversity of crinoids, may be related in part to the depth of the shelf.

Isopod crustaceans are a second group that is well represented both in the deep sea and on the Antarctic shelf, and this has prompted much discussion about evolutionary links between the continental shelves at high southern latitudes and the deep-sea fauna. Menzies et al. (1973) analyzed the depth ranges of the various components of the Southern Ocean isopod fauna and demonstrated a complex evolutionary history. Some shallow-water taxa moved into deeper water (evolutionary polar submergence), whereas others colonized the continental shelf from deeper water (evolutionary polar emergence; see also Brandt 1991, 1992; Brandt et al. 2007; Zinsmeister \& Feldmann 1984). 
These patterns are clearly linked to the glacial history of Antarctica. Brey et al. (1996) showed that many shelf taxa in Antarctica have more extended bathymetric ranges than do comparable taxa on continental shelves elsewhere, suggesting that movement in and out of deeper water, driven by glacial cycles, may represent a general evolutionary history for the fauna. In summary, exchanges between the shelf and deep sea in Antarctica were aided by the generally deep nature of the shelves, requiring the shelf fauna to tolerate greater hydrostatic pressures than shelf faunas elsewhere, and by the absence of a strong thermal gradient between the deep sea and shallow water in the Southern Ocean.

\section{Benthic Ecology of the Antarctic}

Benthic work in the Antarctic has been concentrated at a relatively small number of sites, and the ecologies of those assemblages have influenced much of our thinking about benthic ecology in the Southern Ocean. Particularly important have been studies of soft substrata in McMurdo Sound and along the Antarctic Peninsula, and investigations of suspension-feeding communities in the Weddell and Ross Seas.

A critical feature of benthic ecology in Antarctica is that skeleton-crushing predation (durophagy) is very limited at present (Arntz et al. 1994, Dayton et al. 1974, Dell 1972, McClintock \& Baker 1997). Evolutionarily modern (i.e., post-Paleozoic), durophagous predators-fish and decapods_-are largely responsible for structuring food webs in subtidal marine communities at temperate, subtropical, and tropical latitudes. In contrast, there are no brachyuran crabs, lobsters, sharks, or rays in Antarctica; the diversity and abundance of skates (Rajidae) are low; and the teleostean fauna is dominated by two nondurophagous clades, namely the notothenioids and the liparids (Clarke \& Johnston 1996, 2003; Dayton et al. 1994; Eastman \& Clarke 1998; Long 1992, 1994). Weddell seals feed at depth, but their diet consists primarily of freeswimming prey such as fish and squid; although these seals take benthic prey occasionally, there are no marine mammals in Antarctica that are ecologically equivalent to the durophagous, bottom-feeding walruses or gray whales of the Arctic.

Lacking modern predators, benthic communities in Antarctica are functionally Paleozoic, with clear affinities to archaic, deep-sea biotas: slow-moving invertebrates, including asteroids and nemerteans, are generally the top predators of invertebrates, and dense populations of epifaunal suspension feeders, including ophiuroids, crinoids, bryozoans, and brachiopods, are widespread in shallow-water environments (Arntz et al. 2005, Aronson \& Blake 2001, Clarke et al. 2004, Gili et al. 2006). As with all faunas, however, the benthic fauna is a mixture of relict species, taxa that arrived from elsewhere, and taxa that have evolved in situ (Clarke \& Crame 1989). Thus, although the overall appearance of the fauna may be archaic, the taxa themselves are not necessarily ancient or primitive, and many are highly derived (Aronson et al. 1997).

In the Southern Ocean, suspension-feeding assemblages can cover large areas of the seafloor. Antarctic suspension-feeding communities can extend continuously for hundreds of kilometers and develop a complex, three-dimensional, tiered structure (Gili et al. 2006). Although these Antarctic communities are typically quite deep and
Durophagy:

skeleton-crushing predation

Epifaunal suspension

feeder: an animal that lives on the sediment surface and meets its energetic requirements by filtering organic particles from the water column 
ACC: Antarctic

Circumpolar Current

thus subject to greatly reduced ice-scour, rich suspension-feeding communities also exist at depths less than $100 \mathrm{~m}$ (Raguá-Gil et al. 2004).

\section{Predation in the Arctic}

In the Arctic, durophagous teleosts feed in shallow-water, soft-substratum habitats. These teleosts, which include cod (Gadidae), flatfish (Pleuronectidae), sculpins (Cottidae), and eelpout (Zoarcidae), avoid mortality from cold sea temperatures by means of antifreeze proteins, other biochemical adaptations, and migratory behaviors (Helfman et al. 1997). The dogfish Squalus acanthias (Squalidae) is the most common shark in shallow Arctic waters. Although S. acanthias eats small crabs occasionally, its diet consists primarily of fish. Crabs do not occur naturally in shallow benthic communities in the Arctic. As mentioned above, walruses and gray whales are important sources of disturbance and durophagy in Arctic soft-substratum communities. The oceanographic and ecological differences between Arctic and Antarctic marine ecosystems are reviewed elsewhere (Dayton et al. 1994, Smetacek \& Nicol 2005).

\section{Origin and Isolation of the Antarctic Fauna}

It is now generally accepted that the marine fauna of the Antarctic continental shelf has a long history of evolution in situ (Clarke \& Crame 1989, Dell 1972, Knox \& Lowry 1977, Lipps \& Hickman 1982). Phylogenetic analyses (e.g., Brandt 1991, 1992) show that older groups have an evolutionary history extending back before the fragmentation of Gondwana. Biogeographic analyses also show that taxa migrated to and from what is now Antarctica along the Scotia arc (Dell 1972, Knox \& Lowry 1977). A high degree of endemism in the Southern Ocean (Arntz et al. 1997) highlights the length of time during which the fauna has been isolated (Clarke \& Crame 1997).

The Southern Ocean has long been regarded as one of the most clearly defined large marine ecosystems on earth, being bounded by the Antarctic Continent to the south and the Polar Front to the north. The Polar Front is the most intense of a series of eastward-flowing jets of the Antarctic Circumpolar Current (ACC) and represents a physical barrier to free north/south exchange of water. Visible as a sharp change in surface water temperatures and detectable to significant depths $(>1000 \mathrm{~m})$, it marks a distinct biogeographic discontinuity. With the exception of migratory seabirds and marine mammals, few epipelagic or benthic taxa have distributions both inside and outside the Southern Ocean (Dell 1972).

There are, however, strong biogeographic links between the benthic marine faunas of the Antarctic Peninsula and the Magellan Region of South America (Arntz et al. 2005). The traditional interpretation of these affinities is that the two regions were once contiguous and that only during the Cenozoic have they been separated by the deep waters of Drake Passage and development of the Polar Front. Although the possibility of a continued low level of faunal exchange has been recognized (Dell 1972), it is usually assumed that the strength of the ACC and the intensity of the associated Polar Front render this a rare event; however, there are observations of Antarctic plankton well to the north of the Polar Front (Antezana 1999, Hodgson 
et al. 1997), and it has long been recognized that pumice and driftwood can move both into and out of the Southern Ocean (Barber et al. 1959, Coombs \& Landis 1966).

Observations by Thatje \& Fuentes (2003) highlight the permeability of the Polar Front. They reported zoeal stages of anomuran and brachyuran crabs associated with specimens of the Subantarctic copepod genus Acartia from the waters off King George Island, Antarctic Peninsula $\left(62^{\circ} \mathrm{S}\right)$. Five early zoeal stages were assigned to the (anomuran) mole crab Emerita sp., which is known from shallow waters off sandy beaches, and two early and two advanced zoea were assigned to the brachyuran genus Pinnotheres.

These observations raise questions about how the organisms got to Antarctica and how often this might happen. Thatje \& Fuentes (2003) suggested that the larvae might have crossed the Polar Front by means of eddies or more substantial intrusions of Subantarctic water masses through the ACC. Far from being a continuous, welldefined barrier, the ACC has an exceedingly complex mesoscale structure. The detail now available from satellite imagery reveals a highly variable and dynamic structure, including eddies over a wide range of scales (Glorioso et al. 2005, Olbers et al. 2004). Eddies are an important mechanism for transport of organisms across the ACC: warm-core rings can transport subantarctic plankton, including larvae, to Antarctica, and cold-core rings can carry Antarctic plankton into the warmer waters to the north.

How frequently these events transport biota across the Polar Front is difficult to estimate, but given that even low levels of current and historical sampling have revealed several such events in modern times, it is clear that the Southern Ocean is far from isolated. In fact, the porosity of oceanographic features has exerted a significant influence on the evolution of the Southern Ocean fauna. Using molecular techniques, Page \& Linse (2002) described speciation and dispersal of limatulid bivalves across the Polar Front well after the formation of the ACC, suggesting that neither the ACC nor the Polar Front has been an absolute physical barrier to invasion.

There are, of course, other mechanisms that can transport marine organisms across the Polar Front. Particularly important for encrusting biota are pumice and driftwood, and for a range of organisms, kelp rafts (Helmuth et al. 1994, Highsmith 1985). More recently, humans have increased the likelihood of introduction of new organisms to Antarctica through increases in anthropogenic flotsam (Barnes 2002) and in the frequency with which ships cross the Polar Front (Barnes et al. 2006).

\section{PREDATION IN DEEP TIME}

The reduced level of durophagy in Antarctica and the peculiar composition of the shallow bottom fauna can be traced to a global cooling trend that began late in the Eocene, about $40 \mathrm{Mya}$ (million years ago). In this section we trace the history of predation and its effects on benthic faunas through the Phanerozoic, concentrating on post-Paleozoic patterns and processes. We then apply inferences about escalating predation in the Mesozoic to events in Antarctica during the Eocene.
Mya: million years ago 
Neoselachians: modern sharks, skates, and rays

\section{Phanerozoic Patterns of Predation}

Durophagous predation increased several times during the Phanerozoic, but the fossil record suggests that some of the most significant changes occurred as part of the Mesozoic marine revolution (Aberhan et al. 2006, Vermeij 1977). Modern, skeletonbreaking predators, particularly teleosts, neoselachians, and decapod crustaceans, began to diversify in nearshore environments during the Jurassic (Thies \& Reif 1985; Vermeij 1987). Radiations of durophagous taxa are thought to have driven the evolution of architectural defenses in a variety of marine invertebrates during the Mesozoic and Cenozoic. In gastropods, adaptations of the shell to increasing predation pressure included increased spination, ribbing, and other defensive sculpture (Vermeij 1977, 1987).

The coleoid cephalopods-those forms, including octopus, squid, and cuttlefish, that lack an external shell—radiated beginning in the Mesozoic, at least partially in response to the evolution of skeleton-crushing fish and marine reptiles. The slow-moving, externally shelled (ectocochleate) cephalopods-ammonoids and nautiloids-came under increasing predation pressure in nearshore environments. The faster-moving, fish-like coleoids radiated into a variety of niches in nearshore environments that had been vacated by extinction and ecological displacement of the ectocochleates (Aronson 1991; Packard 1972). Octopods are predators of skeletonized invertebrates in shallow benthic communities at temperate and tropical latitudes, and they can be significant consumers in some situations.

A direct consequence of increased predation, evident at multiple spatio-temporal scales, is a decline in the occurrence of dense populations of prey. Dense populations of epifaunal, suspension-feeding ophiuroids are excluded from most modern coastal environments by predatory fish and crabs (Aronson 1989). The primary predators of epifaunal ophiuroids living in dense populations are slow-moving invertebrates, including asteroids and polychaetes, and the low levels of predation the ophiuroids experience are reflected in low frequencies of sublethal arm damage (regenerating arms). On a macroecological-macroevolutionary scale, the diversification of durophagous predators during the Mesozoic caused a global decline in the occurrence of these dense, low-predation ophiuroid populations in shallow-water habitats (Aronson 1992).

The Mesozoic-Cenozoic escalation in predation resulted from radiations in nearshore environments of taxa comprising the "Modern evolutionary fauna" (sensu Sepkoski 1991). The Modern fauna, which is rich in mollusks, active bioturbators, and durophagous predators, replaced the "Paleozoic evolutionary fauna" in coastal environments. The Paleozoic fauna, rich in brachiopods, bryozoans, echinoderms, and other epifaunal, suspension-feeding taxa (as well as ectocochleate cephalopods), was progressively restricted to more offshore, deeper-water habitats as the Modern fauna spread from onshore to offshore environments. Durophagous predators originated onshore, largely eliminating epifaunal, suspension-feeding populations from soft-substratum habitats (Jablonski \& Bottjer 1991, Sepkoski 1991). From the Jurassic onward, epifaunal suspension feeders on soft substrata were replaced by infaunal and more mobile epifaunal suspension feeders, giving onshore soft-substratum communities their modern, bivalve-dominated ecology (Aberhan et al. 2006, Bottjer 
\& Ausich 1986, Stanley 1977). As a broad generalization, predation is lower and community structure is archaic in offshore, deep-water habitats compared to nearshore, shallow-water habitats.

The decline of dense ophiuroid populations in coastal waters during the Mesozoic is one aspect of this onshore-offshore trend. Another is that stalked crinoids were abundant in shallow water in the Paleozoic and early Mesozoic (Bottjer \& Jablonski 1988, Meyer \& Macurda 1977). Living stalked crinoids, most of which are in the order Isocrinida, occur only offshore, in water deeper than $\sim 100 \mathrm{~m}$, where predation pressure is reduced (Oji 1996). The unstalked crinoids (order Comatulida), which are mobile, replaced the stalked crinoids in shallow-water environments (Meyer \& Macurda 1977).

Predator-prey dynamics evolved within the context of macroevolutionary events and trends. The end-Permian mass extinction accelerated diversification of the Modern evolutionary fauna and increased the complexity of post-Paleozoic onshore communities, perhaps by creating an ecological vacuum of vacant niches (Sepkoski 1991, Wagner et al. 2006). The rapid escalation of predator-prey interactions during the Mesozoic also coincided with increased productivity (Vermeij 1987). More energy permitted the construction of more elaborate antipredatory shell architectures and enabled infauna to dig more actively and to greater depths (Bambach 1993). Thus, increased productivity helped drive the post-Paleozoic radiation of (infaunal) bivalves. These evolutionary innovations of predators and prey transcended the endCretaceous mass extinction, and escalation continued in the Cenozoic. Episodes of elevated extinction in the Cenozoic selectively exterminated well-defended prey taxa, temporarily reversing escalatory trends (Vermeij 1987).

Recent work on living communities in the Adriatic Sea corroborates the idea that both increasing durophagous predation and increasing productivity drove the post-Paleozoic infaunalization of suspension-feeding assemblages in shallow-water, soft-substratum environments. Given the background condition of low predation in the Adriatic, areas of low productivity support Paleozoic-type dense assemblages of epifaunal suspension feeders. Areas of high productivity are characterized by Modern-style assemblages of more energetic, infaunal suspension and deposit feeders (McKinney \& Hageman 2006). The same pattern holds in Antarctica, with retrograde, epifaunally dominated benthic communities requiring oligotrophic conditions in addition to low levels of predation (Dayton \& Oliver 1977).

\section{Antarctica from the Eocene to the Present}

In the late Eocene to early Oligocene, global cooling reduced sea temperatures in Antarctica, with a drop of $4-9^{\circ} \mathrm{C}$ in both open-ocean and coastal environments (Dutton et al. 2002, Ehrmann \& Mackensen 1992, Kennett \& Warnke 1992, Mackensen \& Ehrmann 1992). The opening of the Drake Passage during the Eocene, as early as 41 Mya (Scher \& Martin 2006), and the consequent establishment of circum-Antarctic circulation, drove the long-term shift from the cool-temperate climate of the Eocene to the glaciated, polar climate in Antarctica today (Ivany et al. 2006, Tripati et al. 2005, Zachos et al. 2001). Climatic cooling reduced predation 
pressure, causing a fundamental shift in the structure of benthic communities in Antarctica.

Most of what we know about this critical time in the history of the Antarctic benthos comes from studies of the shallow-water paleoenvironments represented in the La Meseta Formation at Seymour Island off the Antarctic Peninsula. La Meseta time extends from late in the early Eocene through the end of the late Eocene, or 52-33.5 Mya (Dutton et al. 2002). Sea temperatures at Seymour Island dropped from $\sim 14^{\circ} \mathrm{C}$ in the middle Eocene, $45 \mathrm{Mya}$, to $<10^{\circ} \mathrm{C}$ in the late Eocene, $35 \mathrm{Mya}$ (Dutton et al. 2002, Ivany et al. 2004).

Prior to the late Eocene cooling event (i.e., lower in the formation), the benthic fauna was broadly typical of Cenozoic faunas elsewhere: it was dominated by bivalve and gastropod mollusks. Significant changes occurred in the composition of molluscan assemblages as cooling proceeded (Stilwell \& Zinsmeister 1992). In functional terms, the gastropods display a notable decline upsection in the expression of defensive architectural features (Werner et al. 2004).

Twelve dense, autochthonous assemblages of suspension-feeding echinoderms, including ophiuroids (Ophiura hendleri) and stalked, isocrinid crinoids (Metacrinus fossilis), were recovered from the uppermost portion of the La Meseta Formation (representing cold conditions), whereas none were found in the rest of the section below (representing warmer conditions). The presence of dense concentrations of these taxa in a nearshore-shelf setting, and the low frequencies of sublethal injury (regenerating arms) in their populations, indicates that predation pressure from durophagous predators was reduced when temperatures were cooler (Aronson \& Blake 2001, Aronson et al. 1997). Dense populations of other epifaunal suspension feeders, including the comatulid crinoid Notocrinus rasmusseni and the hiatellid bivalve Hiatella tenuis, also appear in the upper La Meseta Formation, supporting the hypothesized decline in importance of durophagous predators.

Dense clusters of tens to hundreds of terebratellid brachiopods, Bouchardia antarctica, occur throughout the La Meseta Formation (Bitner 1996, Wiedman \& Feldmann 1988) and are reminiscent of brachiopod-rich Paleozoic faunas. Unlike the predation-sensitive echinoderms, brachiopods are only incidentally affected by durophagous predators (Kowalewski et al. 2005) and so could persist both before and after the cooling-mediated decline in predation pressure. Brachiopods are low-energy suspension feeders (James et al. 1992, Rhodes \& Thompson 1993), making it possible for dense populations to persist during times of both low or fluctuating productivity prior to the cooling trend, and during periods of sporadically high productivity as sea temperatures dropped (see Diester-Haass \& Zahn 1996, Scher \& Martin 2006).

Isolated bones of teleosts are infrequent and scattered throughout the La Meseta Formation. Shark remains are concentrated in the lower portions, deposited before the cooling began, and there is only one record of skate teeth (Long 1992, 1994). It is not known when the early Tertiary fish fauna became extinct, but molecular evidence puts the endemic nototheniod radiation approximately in the middle Miocene, coincident with a decline in temperature (Cheng \& Chen 1999).

Crab fossils occur throughout the La Meseta Formation, but again they are concentrated in the lower portions (Feldmann \& Wilson 1988). Their subsequent 
decline is poorly constrained, because there are only three species of post-Eocene fossil decapods known from Antarctica: a brachyuran crab and a lobster from the early Miocene, and a palinurid (spiny) lobster from the Pliocene (Feldmann \& Schweitzer 2006). Sea temperatures in the Southern Ocean may have been warm during both the early Miocene and the Pliocene (Hillenbrand \& Ehrmann 2005, Quilty 1990, Zachos et al. 2001), possibly allowing incursions of reptant decapods. In contrast, isopods probably radiated during the cooling trends of the Oligocene and Miocene (Brandt 1991, 2000; Brandt et al. 1998), and they appear to have evolved to occupy many of the benthic niches vacated by the extinctions of decapods.

The few available fossils of durophagous predators do not by themselves yield much insight into temporal trends in predation. What we do know is that (a) durophagous predators currently are absent from marine communities in Antarctica; (b) the porous ACC and the Scotia arc provide avenues for benthic faunal elements to invade Antarctica; and therefore, $(c)$ physiological constraints rather than geographic barriers are keeping the durophagous predators out.

\section{PHYSIOLOGICAL LIMITS TO DUROPHAGOUS PREDATION}

\section{General Considerations}

Variation in the solubility of calcium carbonate $\left(\mathrm{CaCO}_{3}\right)$ with latitude is often cited as an important factor shaping the polar marine fauna. Durophagous fish and crustaceans utilize heavily calcified teeth and chelae, respectively, and heavy calcification is a mainstay of the antipredatory defenses of skeletonized prey. The solubility of $\mathrm{CaCO}_{3}$ varies inversely with temperature, being greater in polar waters than in the tropics (Revelle \& Fairbridge 1957). The added cost of depositing $\mathrm{CaCO}_{3}$ from seawater has been used to explain the lack of durophagous predators and the thin shells of mollusks at high latitudes (Arnaud 1974, Vermeij 1978). As a related matter, the slow growth rates of ectotherms living in Antarctic marine environments (Arntz et al. 1994, Peck 2002) could be an impediment to durophagy, because of the time required to produce effective crushing structures or viable architectural defenses.

Some patterns are, however, difficult to explain if $\mathrm{CaCO}_{3}$ deposition is a major constraint at low temperature. Many successful taxa in Antarctica have high skeletonto-tissue ratios. For example, brachiopods both inside Antarctica and at lower latitudes are $93-97.5 \% \mathrm{CaCO}_{3}$ (Peck 1993). Also, groups of both heavily calcified invertebrates (e.g., solitary corals, crinoids, ophiuroids, and calcareous sponges) and lightly calcified taxa (e.g., nemerteans, anthozoans, and amphipods) have species that attain large size in Antarctica (Chapelle \& Peck 1999, 2004). Animals with high skeletal content and trends of increasing size toward the poles would not be expected if the increased cost of calcification at low temperature limited skeletal construction.

\section{Teleosts}

Durophagous predators eat echinoderms, polychaetes, crustaceans, and mollusks, the last requiring the greatest force generation by the predator. Antarctic
Reptant: formerly a taxonomic designation and now a functional term, referring to bottom-dwelling, walking decapods other than benthic shrimp 
Hemolymph: the blood of arthropods, mollusks, and other invertebrates with an open circulatory system benthic-feeding fish take polychaetes, crustaceans, and echinoderms. There are, however, no fish with feeding habits analogous to the subtropical black drum Pogonias cromis (Sciaenidae), or tropical triggerfish (Balistidae), wrasses (Labridae), or balloonfish (Diodontidae), which feed primarily on hard-shelled prey and often include mollusks in their diets.

Notothenioids, the dominant teleosts in shallow benthic communities in Antarctica, are lightly calcified and as a group possess simple conical teeth. In most species the teeth are not ankylosed to the jaw; they are attached via unossified ligaments (Eastman 1993). This arrangement is not suitable for crushing skeletonized prey, because the attachment is too weak to transfer the necessary forces. Species of benthic-feeding notothenioids in Antarctica either have a catholic diet or are ambush predators taking mainly peracarids (Gon \& Heemstra 1990). The liparids, which generally live in deeper water, are not heavily calcified either, nor are they durophagous. The only fish in Antarctica with mouthparts suitable for durophagy are the skates. Raja georgiana consumes a wide range of prey including crustaceans, echinoderms, cnidarians, polychaetes, and fish, but not mollusks or brachiopods (Long 1994). Thus, following the disappearance of durophagous predators after the Eocene, groups radiating in or colonizing the Southern Ocean have not included a taxon with strong crushing mouthparts.

The power output from a given mass of fish muscle at $0^{\circ} \mathrm{C}$ is about one tenth that at $25^{\circ} \mathrm{C}$ (Wakeling \& Johnston 1998). In the absence of other compensating mechanisms, a predatory fish would require as much as ten times the muscle mass to crush heavily skeletonized prey in Antarctica as compared to the tropics. Other physiological attributes of Antarctic teleosts, including the production of antifreeze compounds (Cheng and DeVries 1991, De Vries 1971), the lack of a standard heatshock response (Hofman et al. 2000), and a marked sensitivity to raised temperature (Peck 2005, Peck et al. 2006, Somero \& De Vries 1967), do not impinge directly on the question of whether or not durophagy is viable in benthic communities in Antarctica.

\section{Reptant Decapods and Magnesium}

The physiological considerations elaborated above also apply to the skeleton-crushing reptant decapods. The primary reason they are excluded from Antarctica, however, appears to be their inability to regulate the concentration of magnesium ions in their hemolymph at low temperatures. Ventilation and circulation are inhibited in brachyuran and anomuran crabs by their poor ability to down-regulate $\left[\mathrm{Mg}^{2+}\right]$ below that of seawater (Frederich et al. 2001). High concentrations of magnesium in the hemolymph have relaxant or anesthetic properties, and the narcotic effect is stronger at low temperature. The reductions in heart rate and metabolism caused by high $\left[\mathrm{Mg}^{2+}\right]$ reduce aerobic scope (Frederich et al. 2001). Aerobic scope is the crucial factor setting temperature tolerance limits (Pörtner 2002, Pörtner et al. 2006) and activity limits (Peck et al. 2004) in marine animals.

Elevated hemolymph $\left[\mathrm{Mg}^{2+}\right]$, therefore, explains the absence of reptant decapods in low-temperature environments, setting a lower temperature limit of $0-1^{\circ} \mathrm{C}$ for 
crabs. Among the crabs, the anomuran king crabs (Lithodidae) are the most coldtolerant, especially at the larval stage, within the limits imposed by their inability to regulate magnesium (Anger et al. 2003, Thatje et al. 2005). Caridean shrimp, and peracarids such as isopods and amphipods, are able to down-regulate $\left[\mathrm{Mg}^{2+}\right]$ in their hemolymph below levels found in seawater, which accounts for the predominance of isopods and amphipods in the shallow Antarctic benthos (Frederich et al. 2001).

\section{Neoselachian Sharks}

The absence of sharks from Antarctic waters may be due to interactions of geography, temperature, and physiology. Most sharks are denser than seawater and must swim to remain in the water column, even though large fat stores and accumulation of trimethylamine oxide (TMAO) aid in reducing density (Carrier et al. 2004). Furthermore, fast-moving, pelagic sharks must swim to aerate their gills, incurring a cost in increased metabolism.

The active lifestyles of fast-moving pelagic sharks are hypothesized to be prohibitively expensive in extremely cold, oligotrophic polar environments (Priede et al. 2006). Pelagic cold-water sharks, like other pelagic predators, have metabolic rates five to ten times higher than related benthic species; however, corrected for temperature, these rates are not dramatically different from those of Antarctic teleosts and invertebrates with similar lifestyles at lower temperatures (Carrier et al. 2004, Seibel \& Drazen 2007). All durophagous sharks are benthic and feed on benthic organisms, whereas pelagic sharks feed on fish and squid. Benthic sharks spend most of their time on the substratum, have small home ranges and have a body shape that is not as streamlined as that of pelagic sharks (Carrier et al. 2004).

Accumulating a lipid-rich liver requires a great investment of energy. A lipid store of $20 \%$ mass could support a benthic shark for more than three years. Although it seems counterintuitive, many polar organisms have larger fat stores than their temperate counterparts, perhaps as an adaptation to a seasonally variable food supply. Thus, energetically expensive lifestyles are not precluded by a seasonal food supply, but rather they may be limited by temperature effects on aerobic metabolism (Clarke \& Johnston 1996, Seibel \& Drazen 2007).

Benthic sharks lack the metabolism either to swim continuously in the water column or intermittently traverse the substratum to cross the Southern Ocean to Antarctica. Furthermore, there may be a physiological barrier to reinvasion. Although TMAO, which counters the harmful effects of high pressure and lowers the body freezing point, may be beneficial to sharks in deep-water environments, no sharks have been collected from depths greater than $3700 \mathrm{~m}$ (Priede et al. 2006, Samerotte et al. 2007). It may be that in cold, very deep waters, TMAO amplifies the inwardly directed osmotic gradient, and the kidneys are unable to compensate (Samerotte et al. 2007).

\section{Octopods}

Pareledone is the most abundant and diverse genus of benthic octopods in Antarctica (Allcock et al. 2001). Although present in shallow-water benthic communities, 
Pareledone spp. appear to exert only a minor influence on food-web dynamics. Benthic octopods in Antarctica eat a variety of prey, including amphipods, polychaetes, gastropods, bivalves, ophiuroids, and fish (Daly 1996, Piatkowski et al. 2003).

The metabolic rates of benthic octopods across latitudes can be described by a single relationship incorporating mass and temperature (Seibel 2007). Polar octopods are slower in terms of metabolism and activity than their temperate and tropical counterparts. They do not possess adaptations to compensate for the depression of metabolic rate in their cold environment (Daly \& Peck 2000).

\section{THE RETURN OF DUROPHAGOUS PREDATORS}

\section{Recent Invasions}

The first indication that alien predators had invaded Antarctica came from records of adult male and female brachyuran crabs, Hyas araneus, occurring off King George Island in 1986 (Tavares \& De Melo 2004). H. araneus is a spider crab (Majidae) from the Northern Hemisphere, which ranges from boreal to Subarctic waters. It could have been introduced to Antarctica via the transport of adults on ships' hulls or larvae in ballast water (Barnes et al. 2006, Tavares \& De Melo 2004). This first record of $H$. araneus, which is physiologically preadapted to conditions in the Southern Ocean, serves as a warning of their potential threat to Antarctic benthic communities.

Large populations of predatory king crabs (Lithodidae) native to the Southern Hemisphere were recently discovered in deep-water, continental-slope environments off the Antarctic Peninsula (Thatje \& Arntz 2004, Thatje \& Lörz 2005). Lithodids are common at high latitudes in both hemispheres and are frequent in the deep sea. In the Southern Hemisphere they were, however, believed to be entirely Subantarctic (Dawson 1989). In recent years the number of lithodid species known from the Southern Ocean has increased to about 14 species (Ahyong \& Dawson 2006, Thatje \& Lörz 2005, Thatje et al. 2005), including records of Neolithodes capensis and Paralomis birsteini described from the Antarctic continental slope in the Bellingshausen Sea (García Raso et al. 2005). It may be more than coincidental that a northern lithodid, Lithodes maja, was recently recorded for the first time off southeast Greenland (Woll \& Burmeister 2002).

The timescale over which lithodids would be capable of colonizing Antarctica remains unclear (Thatje et al. 2005). They possess demersally drifting larvae, making range expansions over long distances improbable (Thatje et al. 2005). On the other hand, their larvae are lecithotrophic, with embryonic development lasting as long as two years. Adults are long-lived and grow very slowly (Lovrich \& Vinuesa 1999). Low metabolism and adjustment of all life history stages to low temperatures may be the keys to ecological success for this group in polar seas (Kattner et al. 2003, Pörtner 2002, Thatje et al. 2005).

\section{Limits to Invasibility}

New discoveries of lithodids in Antarctica could represent recent invasions, but at least some of these new records simply reflect the inadequacy of earlier observations 
(García Raso et al. 2005). Our understanding of the history of lithodids in Antarctica is further obscured by the fact that some species could be endemic. Ambient temperatures in deep-water, slope habitats are high enough to support lithodids in a torpid, hypometabolic state (Thatje et al. 2005). Regardless of how long they have been in Antarctica, however, they remain absent from shallow-shelf habitats, where water temperatures remain too low.

The lower temperature threshold of two Subantarctic lithodid species is $\sim 1^{\circ} \mathrm{C}$, a direct consequence of the problems of magnesium regulation (Thatje et al. 2005). Although physiological data are lacking for lithodids found south of the Polar Front, the $1^{\circ} \mathrm{C}$ threshold corresponds to the temperature of the Upper Circumpolar Deep Water, which characterizes the deep-water locations of, for example, Lithodes murrayi in the Bellingshausen Sea (Klages et al. 1995). Typical sea temperatures on the Antarctic continental shelf are lower, particularly on the Weddell and Ross Sea shelves where they routinely fall below $0^{\circ} \mathrm{C}$. This suggests that at present most of the Antarctic shelf is unsuitable for lithodids to establish viable populations.

Should the sea-surface warming demonstrated for the western Antarctic Peninsula - a rise of more than $1^{\circ} \mathrm{C}$ in the past 50 years (Meredith \& King 2005) extend deeper into the water column, lithodids from deep water could colonize shallow waters along the Peninsula. Lithodids are generalist predators, feeding on echinoderms, benthic mollusks, and bryozoans (Comoglio \& Amin 1999). Their invasion of shallow-water habitats off the Antarctic Peninsula would have significant consequences for benthic community structure.

Other anomuran and brachyuran crabs from southern South America would be likely candidates for invasion if sea temperatures increased significantly. At this point a severe impediment to invasion is the mismatch between the short Antarctic growing season and the longer development times of planktotrophic larvae (Thatje et al. 2003). Rising sea temperatures and continued breakup of the ice shelves should both increase phytoplankton productivity and prolong the growing season (Doney 2006, Smetacek $\&$ Nicol 2005). These effects should better synchronize development times with the annual period during which phytoplankton are readily available. Rising temperatures should also speed larval development (O'Connor et al. 2007, Peck et al. 2006), which could either reduce or increase the mismatch.

The diversity of sharks is high on outer shelves and slopes in cool-temperate environments (Carrier et al. 2004). There is, therefore, a high probability that fast-moving, pelagic shark species would reinvade Antarctic waters if sea temperatures continued to increase. For benthic, durophagous sharks, however, the problem remains of crossing deep ocean to reach shallow Antarctic waters. Demersal, durophagous teleosts, which produce planktonic larvae, could invade more easily than benthic sharks if temperatures in shallow water increased to the point that antifreeze proteins became unnecessary.

Lack of suitable habitat in Antarctica would prevent some invasions. For example, larvae of the mole crab Emerita sp. would not be able to settle and metamorphose without sandy-beach habitat, which is virtually absent from Antarctica. On the other hand, warming sea temperatures might cause physiological problems for shallowwater, Antarctic cold-stenotherms, which could soon be exposed to conditions 
Figure 2

Physiological

temperature-tolerance window and cumulative mortality in all larval stages of the spider crab Hyas araneus. In nature, the benthic megalopa stage usually encounters temperatures ranging from 5 to $13^{\circ} \mathrm{C}$; successful larval development and, thus, survival at low temperatures typical of shallow Antarctic seas $\left(<1^{\circ} \mathrm{C}\right)$ is unlikely. Redrawn from Thatje (2005).

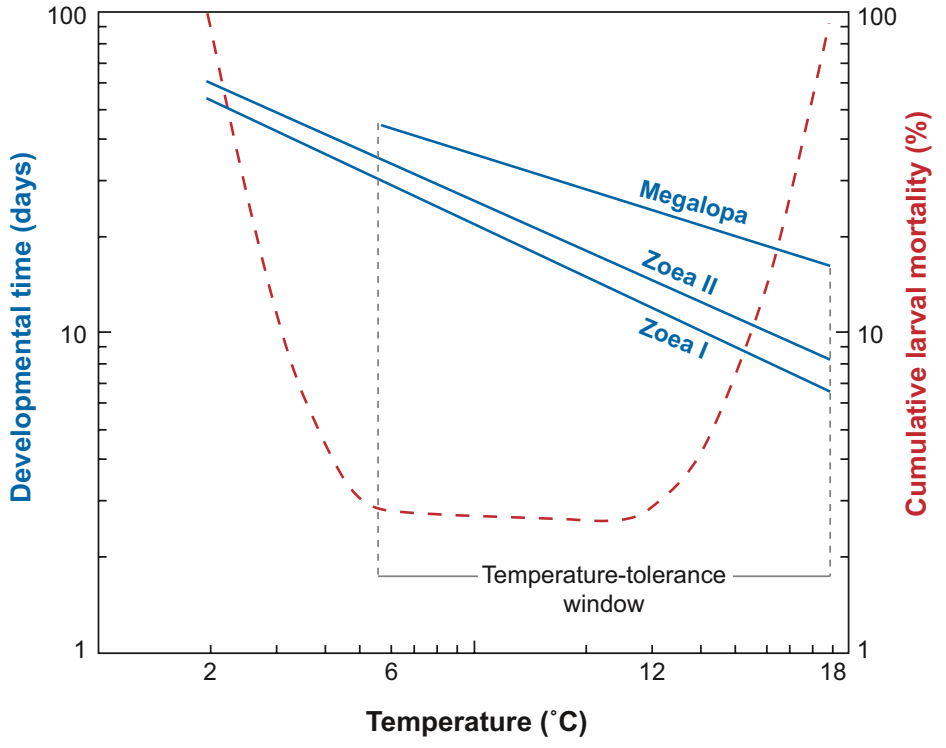

approaching their upper temperature thresholds (Clarke et al. 2007, Peck 2005, Pörtner 2002). Physiological stress, increased mortality, and lowered recruitment success of native species could open ecological niche space for invading predators, which would be at a competitive advantage.

Under present climatic conditions, the introduction of Subarctic and Arctic species in ballast water or as fouling organisms on ships' hulls continues to be a cause for serious concern. Because they are cold-adapted, these species have the potential to establish viable populations rapidly in Antarctica. The record of two adult Hyas araneus from Antarctica raises the question of how these Subarctic brachyurans managed, as larvae or adults, to survive the transit through tropical seas at temperatures lethal to this species (Figure 2). Development of double-hulled ships in the 1980s has increased the thermal insulation of ballast water, potentially increasing the survival of alien organisms as they are transported across the oceans. Increased ship traffic into and out of Antarctica is increasing the risk of faunal exchange and the establishment of alien species. Such invaders will themselves be faced with changing ambient conditions fostered by global warming.

\section{CONCLUSION}

Beginning in the late Eocene, global cooling reduced durophagous predation in Antarctica. Despite some climatic reversals, the post-Eocene cooling trend drove shallow-water, benthic communities to the retrograde, Paleozoic-type structure and function we see today. Now, global warming is facilitating the return of durophagous predators, which are poised to eliminate that anachronistic character and remodernize the Antarctic benthos in shallow-water habitats. Rising sea temperatures should 
in general act to reduce the mismatch between the development times of invasive larvae and the length of the growing season. Increased survivability of planktotrophic larvae will decrease the selective advantage of brooding and lecithotrophy, increasing the pool of potentially invasive species. Warming temperatures will also increase the scope for more rapid metabolism and should ultimately obviate the adaptive value of gigantism. All of these effects appear destined to amplify the ongoing, worldwide homogenization of marine biotas by reducing the endemic character of the Antarctic fauna.

The fact that benthic predators are already beginning to invade the Antarctic Peninsula should be taken as an urgent warning. Controlling the discharge of ballast water from ships will be difficult but not impossible. Whether or not humans are the proximal vectors, however, the long-term threat of invasion in Antarctica has its roots in climate change. The Antarctic Treaty cannot control global warming. Global environmental policy must immediately be directed to reducing and reversing anthropogenic emissions of greenhouse gases into the atmosphere if marine life in Antarctica is to survive in something resembling its present form.

\section{SUMMARY POINTS}

1. Shallow-water, benthic communities in Antarctica are functionally similar to communities of the Paleozoic and the modern deep sea.

2. The historical absence of skeleton-crushing (durophagous) predators is an important reason for the archaic character of the Antarctic bottom fauna.

3. Durophagous predators disappeared as sea temperatures declined, beginning in the late Eocene (approximately $40 \mathrm{Mya}$ ).

4. The barriers to reinvasion by durophagous predators are physiological (intolerance of cold temperatures) rather than geographic or oceanographic.

5. Durophagous king crabs have recently been discovered on the continental slope off the Antarctic Peninsula.

6. Warming temperatures could facilitate the return of king crabs and other predators to shallow-shelf habitats.

7. Viable populations of durophagous predators would radically alter the structure of benthic food webs in Antarctica.

\section{FUTURE ISSUES}

1. Document ongoing invasions through continued long-term monitoring of the plankton and the benthos.

2. Determine experimentally whether physiologies and life histories of actual and potential invaders are amenable to warming sea temperatures in Antarctica. 
3. Monitor and experiment on shallow benthic communities to detect and predict incipient changes to food-web structure.

4. Expand the scope of ecological observations beyond a few intensively studied areas.

\section{DISCLOSURE STATEMENT}

The authors are not aware of any biases that might be perceived as affecting the objectivity of this review.

\section{ACKNOWLEDGMENTS}

We thank Bill Baker, Alistair Crame, Rodney Feldmann, Alexander Glass, Drew Harvell, Linda Ivany, David Jablonski, Susan Kidwell, James McClintock, Ryan Moody, Sean Powers, Victor Smetacek, Jan Strugnell, Simon Thrush, John Werner, and William Zinsmeister for helpful advice and discussion. The impetus to write this review came from a workshop on The Role of the Southern Ocean in Global Processes, organized by the British Antarctic Survey and held at The Royal Society, London, in July 2003. Many of the ideas expressed here grew out of research funded by the U.S. National Science Foundation's Office of Polar Programs (grants OPP-9908828 and ANT-0245563 to R.B.A., and OPP-9908856 to D.B.B.). This is Contribution No. 385 from the Dauphin Island Sea Lab.

\section{LITERATURE CITED}

Aberhan M, Kiessling W, Fürisch FT. 2006. Testing the role of biological interactions in the evolution of mid-Mesozoic marine benthic ecosystems. Paleobiology 32:259-77

Ahyong ST, Dawson EW. 2006. Lithodidae from the Ross Sea, Antarctica, with descriptions of two new species (Crustacea: Decapoda: Anomura). Zootaxa 1303:45-68

Allcock AL, Piatkowski U, Rodhouse PGK, Thorpe JP. 2001. A study on octopodids from the eastern Weddell Sea, Antarctica. Polar Biol. 24:832-38

Anderson JB. 1999. Antarctic Marine Geology. Cambridge: Cambridge Univ. Press. 289 pp.

Anger K, Thatje S, Lovrich G, Calcagno J. 2003. Larval and early juvenile development of Paralomis granulosa reared at different temperatures: tolerance of cold and food limitation in a lithodid crab from high latitudes. Mar. Ecol. Prog. Ser. 253:243-51

Antezana T. 1999. Plankton of southern Chilean fjords: trends and linkages. Sci. Mar. 63(Suppl. 1):69-80 
Arnaud PM. 1974. Contribution à la bionomie marine benthique des régions antarctiques et subantarctiques. Téthys 6:567-653

Arntz WE, Brey T, Gallardo VA. 1994. Antarctic zoobenthos. Oceanogr. Mar. Biol. Ann. Rev. 32:241-304

Arntz WE, Gutt J, Klages M. 1997. Antarctic marine biodiversity: an overview. In Antarctic Communities: Species, Structure and Survival, ed. B Battaglia, J Valencia, DWH Walton, pp. 3-14. Cambridge: Cambridge Univ. Press

Arntz WE, Thatje S, Gerdes D, Gili J-M, GuttJ, et al. 2005. The Antarctic-Magellan connection: macrobenthos ecology on the shelf and upper slope, a progress report. Sci. Mar. 69(Suppl. 2):237-69

Aronson RB. 1989. Brittlestar beds: low-predation anachronisms in the British Isles. Ecology 70:856-65

Aronson RB. 1991. Ecology, paleobiology and evolutionary constraint in the octopus. Bull. Mar. Sci. 49:245-55

Aronson RB. 1992. Biology of a scale-independent predator-prey interaction. Mar. Ecol. Prog. Ser. 89:1-13

Aronson RB, Blake DB. 2001. Global climate change and the origin of modern benthic communities in Antarctica. Am. Zool. 41:27-39

Aronson RB, Blake DB, Oji T. 1997. Retrograde community structure in the late Eocene of Antarctica. Geology 25:903-6

Bambach RK. 1993. Seafood through time: changes in biomass, energetics, and productivity in the marine ecosystem. Paleobiology 19:372-97

Barber HN, Dadswell HE, Ingle HD. 1959. Transport of driftwood from South America to Tasmania and Macquarie Island. Nature 184:203-4

Barnes DKA. 2002. Invasions by marine life on plastic debris. Nature 416:808-9

Barnes DKA, Hodgson DA, Convey P, Allen CS, Clarke A. 2006. Incursion and excursion of Antarctic biota: past, present and future. Glob. Ecol. Biogeogr. 15:12142

Bitner MA. 1996. Brachiopods from the Eocene La Meseta Formation of Seymour Island, Antarctic Peninsula. Palaeontol. Polon. 55:65-100

Bottjer DJ, Ausich WI. 1986. Phanerozoic development of tiering in soft substrata suspension-feeding communities. Paleobiology 12:400-20

Bottjer DJ, Jablonski D. 1988. Paleoenvironmental patterns in the evolution of postPaleozoic benthic marine invertebrates. Palaios 3:540-60

Brandt A. 1991. Zur Besiedlungsgeschichte des antarktischen Schelfes am Beispiel der Isopoda (Crustacea, Malacostraca). Ber. Polarforsch. 98:1-240

Brandt A. 1992. Origin of Antarctic Isopoda (Crustacea, Malacostraca). Mar. Biol. $113: 15-23$

Brandt A. 2000. Hypotheses on Southern Ocean peracarid evolution and radiation (Crustacea, Malacostraca). Antarct. Sci. 12:269-75

Brandt A, Crame JA, Polz H, Thomson MRA. 1998. Late Jurassic Tethyan ancestry of Recent southern high-latitude marine isopods (Crustacea, Malacostraca). Palaeontology 42:663-75

Brandt A, Gooday AJ, Brandão SN, Brix S, Brökeland W, et al. 2007. First insights into the biodiversity and biogeography of the Southern Ocean deep sea. Nature 447:307-11 
Brey T, Dahm C, Gorny M, Klages M, Stiller M, Arntz WE. 1996. Do Antarctic benthic invertebrates show an extended level of eurybathy? Antarct. Sci. 8:3-6

Carrier JC, Musick J, Heithau M, eds. 2004. Biology of Sharks and their Relatives. Boca Raton: CRC Press. 616 pp.

Chapelle G, Peck LS. 1999. Polar gigantism dictated by oxygen availability. Nature 399:114-15

Chapelle G, Peck LS. 2004. Amphipod crustacean size spectra: new insights in the relationship between size and oxygen. Oikos 106:167-75

Cheng C-HC, Chen LB. 1999. Evolution of an antifreeze glycoprotein. Nature 401:443-44

Cheng C-HC, De Vries AL. 1991. The role of antifreeze glycopeptides and peptides in the freezing avoidance of cold-water fish. In Life under Extreme Conditions: Biochemical Adaptation, ed. G. di Prisco, pp. 1-15. Berlin: Springer-Verlag

Clarke A. 2003. The polar deep seas. In Ecosystems of the Deep Oceans, ed. PA Tyler, pp. 239-60. Amsterdam: Elsevier

Clarke A, Aronson RB, Crame JA, Gili J-M, Blake DB. 2004. Evolution and diversity of the benthic fauna of the Southern Ocean continental shelf. Antarct. Sci. $16: 559-68$

Clarke A, Crame JA. 1989. The origin of the Southern Ocean marine fauna. In Origins and Evolution of the Antarctic Biota, ed. JA Crame, pp. 253-68. London: Geol. Soc., Spec. Publ. 47

Clarke A, Crame JA. 1997. Diversity, latitude and time: patterns in the shallow sea. In Marine Biodiversity: Causes and Consequences, ed. RFG Ormond, JD Gage, MV Angel, pp. 122-47. Cambridge: Cambridge Univ. Press

Clarke A, Johnston IA. 1996. Evolution and adaptive radiation of Antarctic fishes. TREE 11:212-18

Clarke A, Johnston NM. 2003. Antarctic marine benthic diversity. Oceanogr. Mar. Biol. Ann. Rev. 41:47-114

Clarke A, Murphy EJ, Meredith MP, King JC, Peck LS, et al. 2007. Climate change and the marine ecosystem of the western Antarctic Peninsula. Philos. Trans. $R$. Soc. London Ser. B 362:149-66

Comoglio LI, Amin OA. 1999. Feeding habits of the false southern king crab Paralomis granulosa (Lithodidae) in the Beagle Channel, Tierra del Fuego, Argentina. Sci. Mar. 63(Suppl. 1):361-66

Coombs DS, Landis CA. 1966. Pumice from the South Sandwich eruption of March 1962 reaches New Zealand. Nature 209:289-90

Daly HI. 1996. Ecology of the Antarctic Octopus Pareledone from the Scotia Sea. Ph.D. Dissertation. Aberdeen: Univ. Aberdeen. 162 pp.

Daly HI, Peck LS. 2000. Energy balance and cold adaptation in the octopus Pareledone charcoti. 7. Exp. Mar. Biol. Ecol. 245:197-214

Dawson EW. 1989. King crabs of the world (Crustacea: Lithodidae) and their fisheries: a comprehensive bibliography. Misc. Publ. N. Z. Oceanogr. Inst. 101:1-338

Dayton PK, Mordida BJ, Bacon F. 1994. Polar marine communties. Am. Zool. 34:9099

Dayton PK, Oliver JS. 1977. Antarctic soft-bottom benthos in oligotrophic and eutrophic environments. Science 197:55-58 
Dayton PK, Robilliard GA, Paine RT, Dayton LB. 1974. Biological accommodation in the benthic community at McMurdo Sound, Antarctica. Ecol. Monogr. 44:10528

Dell RK. 1972. Antarctic benthos. Adv. Mar. Biol. 10:1-216

De Vries AL. 1971. Glycoproteins as biological antifreeze agents in Antarctic fishes. Science 172:1152-55

Diester-Haass L, Zahn R. 1996. Eocene-Oligocene transition in the Southern Ocean: history of water mass circulation and biological productivity. Geology 24:163-66

Doney SC. 2006. Plankton in a warmer world. Nature 444:695-96

Dutton AL, Lohmann KC, Zinsmeister WJ. 2002. Stable isotope and minor element proxies for Eocene climate of Seymour Island, Antarctica. Paleoceanography $17: 1016-28$

Eastman JT. 1993. Antarctic Fish Biology: Evolution in a Unique Environment. New York: Academic. 322 pp.

Eastman JT, Clarke A. 1998. A comparison of adaptive radiations of Antarctic fish with those of nonantarctic fish. In Fishes of Antarctica: A Biological Overview, ed. G di Prisco, E Pisano, A Clarke, pp. 3-26. Berlin: Springer-Verlag

Ehrmann WU, Mackensen A. 1992. Sedimentological evidence for the formation of an East Antarctic ice sheet in Eocene/Oligocene time. Palaeogeogr. Palaeoclimatol. Palaeoecol. 93:85-112

Feldmann RM, Schweitzer CE. 2006. Paleobiogeography of Southern Hemisphere decapod Crustacea. 7. Paleont. 80:83-103

Feldmann RM, Wilson MT. 1988. Eocene decapod crustaceans from Antarctica. See Feldman \& Woodburne 1988, pp. 465-88

Feldmann RM, Woodburne MO, eds. 1988. Geology and Paleontology of Seymour Island, Antarctic Peninsula. Boulder: Geol. Soc. Am., Mem. 169

Fields PA, Graham JB, Rosenblatt RH, Somero GN. 1993. Effects of expected global climate change on marine faunas. TREE 8:361-67

Frederich M, Sartoris FJ, Pörtner H-O. 2001. Distribution patterns of decapod crustaceans in polar areas: a result of magnesium regulation? Polar Biol. 24:719-23

Gage JD, Tyler PA. 1991. Deep-Sea Biology: A Natural History of Organisms at the Deep-Sea Floor. Cambridge: Cambridge Univ. Press. 504 pp.

García Raso JE, Manjón-Cabeza ME, Ramos A, Olasi I. 2005. New record of Lithodidae (Crustacea, Decapoda, Anomura) from the Antarctic (Bellingshausen Sea). Polar Biol. 28:642-46

Gili J-M, Arntz WE, Palanques A, Orejas C, Clarke A, et al. 2006. A unique assemblage of epibenthic sessile suspension feeders with archaic features in the high-Antarctic. Deep-Sea Res. II 53:1029-52

Glorioso PD, Piola AR, Leben RR. 2005. Mesoscale eddies in the Subantarctic Front, southwest Atlantic. Sci. Mar: 69(Suppl. 2):7-15

Gon O, Heemstra PC. 1990. Fishes of the Southern Ocean. Grahamstown: J.L.B. Smith Inst. Ichthyol. $462 \mathrm{pp}$.

GuttJ, Sirenko BI, Smirnov IS, Arntz WE. 2004. How many macrozoobenthic species might inhabit the Antarctic shelf? Antarct. Sci. 16:11-16 
Held C. 2000. Phylogeny and biogeography of serolid isopods (Crustacea, Isopoda, Serolidae) and the use of ribosomal expansion segments in molecular systematics. Mol. Phylogenet. Evol. 15:165-78

Helfman GS, Colette BB, Facey DE. 1997. The Diversity of Fishes. Oxford: Blackwell. $528 \mathrm{pp}$.

Helmuth B, Mieskowska N, Moore P, Hawkins SJ. 2006. Living on the edge of two changing worlds: forecasting the responses of rocky intertidal ecosystems to climate change. Annu. Rev. Ecol. Evol. Syst. 37:373-404

Helmuth B, Veit RR, Holberton R. 1994. Long distance dispersal of a subantarctic brooding bivalve (Gaimarida trapesina) by kelp-rafting. Mar. Biol. 120:421-26

Highsmith RC. 1985. Floating and algal rafting as potential dispersal mechanisms in brooding invertebrates. Mar. Ecol. Prog. Ser. 25:169-79

Hillenbrand C-D, Ehrmann W. 2005. Late Neogene to Quaternary environmental changes in the Antarctic Peninsula region: evidence from drift sediments. Global Planet. Change 45:165-91

Hodgson DA, Vyverman W, Tyler P. 1997. Diatoms of meromictic lakes adjacent to the Gordon River, and of the Gordon River estuary in south-west Tasmania. Bibl. Diatomol. 35:1-172

Hofmann GE, Buckley BA, Airaksinen S, Keen JE, Somero GN. 2000. Heat-shock protein expression is absent in the Antarctic fish Trematomus bernacchii (Family Nototheniidae). 7. Exp. Biol. 203:2331-39

Huybrechts P. 2002. Sea-level changes at the LGM from ice-dynamic reconstructions of the Greenland and Antarctic ice sheets during the glacial cycles. Quat. Sci. Rev. 22:203-31

Ivany LC, Blake DB, Lohmann KC, Aronson RB. 2004. Eocene cooling recorded in the chemistry of La Meseta Formation mollusks, Seymour Island, Antarctic Peninsula. Boll. Geofis. 45(Suppl. 2):242-45 (Abstr.)

Ivany LC, Van Simaeys S, Domack EW, Samson SD. 2006. Evidence for an earliest Oligocene ice sheet on the Antarctic Peninsula. Geology 34:377-80

Jablonski D, Bottjer DJ. 1991. Environmental patterns in the origins of higher taxa: the post-Paleozoic fossil record. Science 252:1831-33

James MA, Ansell AD, Collins MJ, Curry GB, Peck LS, Rhodes MC. 1992. Recent advances in the study of living brachiopods. Adv. Mar. Biol. 28:175-387

Kattner G, Graeve M, Calcagno JA, Lovrich GA, Thatje S, Anger K. 2003. Lipid, fatty acid and protein utilization during lecithotrophic larval development of Lithodes santolla (Molina) and Paralomis granulosa (Jacquinot). 7. Exp. Mar. Biol. Ecol. 292:61-74

Kennett JP, Warnke DA, eds. 1992. The Antarctic Paleoenvironment: A Perspective on Global Change, Part 1. Washington, DC: Am. Geophys. Union, Antarct. Res. Ser. 56

Klages M, Gutt J, Starmans A, Bruns T. 1995. Stone crabs close to the Antarctic continent: Lithodes murrayi Henderson, 1888 (Crustacea; Decapoda; Anomura) off Peter I Island (68 $\left.51^{\prime} \mathrm{S}, 91^{\circ} 51^{\prime} \mathrm{W}\right)$. Polar Biol. 15:73-75

Knox GA, Lowry JK. 1977. A comparison between the benthos of the Southern Ocean and the North Polar Ocean with special reference to the Amphipoda and 
the Polychaeta. In Polar Oceans, ed. MJ Dunbar, pp. 423-62. Calgary: Arct. Inst. North Am.

Kowalewski M, Hoffmeister AP, Baumiller TK, Bambach RK. 2005. Secondary evolutionary escalation between brachiopods and enemies of other prey. Science 308:1774-77

Lipps JH, Hickman CS. 1982. Origin, age and evolution of Antarctic and deep-sea faunas. In Environment of the Deep Sea, ed. WG Ernst, JG Morris, pp. 324-56. Englewood Cliffs: Prentice Hall

Long DJ. 1992. Paleoecology of Eocene antarctic sharks. See Kennett \& Warnke 1992, pp. 131-39

Long DJ. 1994. Quaternary colonization or Paleogene persistence? Historical biogeography of skates (Chondrichthyes: Rajidae) in the Antarctic ichthyofauna. Paleobiology 20:215-28

Lovrich GA, Vinuesa JH. 1999. Reproductive potential of the lithodids Lithodes santolla and Paralomis granulosa (Anomura, Decapoda) in the Beagle Channel, Argentina. Sci. Mar. 63(Suppl. 1):355-60

Mackensen A, Ehrmann WU. 1992. Middle Eocene through early Oligocene climate history and paleoceanography in the Southern Ocean: stable oxygen and carbon isotopes from ODP sites on Maud Rise and Kerguelen Plateau. Mar. Geol. 108:127

McClintock JB, Baker BJ. 1997. A review of the chemical ecology of Antarctic marine invertebrates. Am. Zool. 37:329-42

McKinney FK, Hageman SJ. 2006. Paleozoic to modern marine ecological shift displayed in the northern Adriatic Sea. Geology 34:881-84

Menzies RJ, George RY, Rowe GT. 1973. Abyssal Environment and Ecology of the World Oceans. New York: Wiley. 488 pp.

Meredith MP, King JC. 2005. Rapid climate change in the ocean west of the Antarctic Peninsula during the second half of the 20th century. Geophys. Res. Lett. 32:L19604

Meyer DL, Macurda DB Jr. 1977. Adaptive radiation of the comatulid crinoids. Paleobiology 3:74-82

O'Connor MI, BrunoJF, Gaines SD, Halpern BS, Lester SE, et al. 2007. Temperature control of larval dispersal and the implications for marine ecology, evolution, and conservation. Proc. Natl. Acad. Sci. USA 104:1266-71

Oji T. 1996. Is predation intensity reduced with increasing depth? Evidence from the west Atlantic stalked crinoid Endoxocrinus parrae (Gervais) and implications for the Mesozoic marine revolution. Paleobiology 22:339-51

Olbers D, Borowski D, Völker C, WölffJ-O. 2004. The dynamical balance, transport and circulation of the Antarctic Circumpolar Current. Antarct. Sci. 16:439-70

Packard A. 1972. Cephalopods and fish: the limits of convergence. Biol. Rev. Camb. Philos. Soc. 47:241-307

Page TJ, Linse K. 2002. More evidence of speciation and dispersal across the Antarctic Polar Front through molecular systematics of Southern Ocean Limatula (Bivalvia: Limidae). Polar Biol. 25:818-26

Pearse JS, McClintock JB, Bosch I. 1991. Reproduction of Antarctic benthic marine invertebrates: tempos, modes, and timing. Am. Zool. 421:37-42 
Peck LS. 1993. The tissues of articulate brachiopods and their value to predators. Philos. Trans. R. Soc. London Ser. B 339:17-32

Peck LS. 2002. Ecophysiology of Antarctic marine ectotherms: limits to life. Polar Biol. 25:31-40

Peck LS. 2005. Prospects for survival in the Southern Ocean: vulnerability of benthic species to temperature change. Antarct. Sci. 17:497-507

Peck LS, Convey P, Barnes DKA. 2006. Environmental constraints on life histories in Antarctic ecosystems: tempos, timings and predictability. Biol. Rev. Camb. Philos. Soc. 81:75-109

Peck LS, Webb K, Bailey D. 2004. Extreme sensitivity of biological function to temperature in Antarctic marine species. Funct. Ecol. 18:625-30

Piatkowski U, Allcock L, Vecchione M. 2003. Cephalopod diversity and ecology. Ber. Polarforsch. 470:32-38

Pörtner H-O. 2002. Physiological basis of temperature-dependent biogeography: trade-offs in muscle design and performance in polar ectotherms. F. Exp. Biol. 205:2217-30

Pörtner H-O, Peck LS, Hirse T. 2006. Hyperoxia alleviates thermal stress in the Antarctic bivalve Laternula elliptica: evidence for oxygen limited thermal tolerance. Polar Biol. 29:688-93

Priede IG, Fröse R, Bailey DM, Bergstad OA, Collins MA, et al. 2006. The absence of sharks from abyssal regions of the world's oceans. Proc. R. Soc. London Ser. B 273:1435-41

Quilty PG. 1990. Significance of evidence for changes in the Antarctic marine environment over the last 5 million years. In Antarctic Ecosystems: Ecological Change and Conservation, ed. KR Kerry, G Hempel, pp. 3-8. Berlin: Springer-Verlag

Raguá-Gil JM, Gutt J, Clarke A, Arntz WE. 2004. Antarctic shallow-water megaepibenthos: shaped by circumpolar dispersion or local conditions? Mar. Biol. 144:29-40

Revelle R, Fairbridge R. 1957. Carbonates and carbon dioxide. Geol. Soc. Am. Mem. 67:239-96

Rhodes MC, Thompson RJ. 1993. Comparative physiology of suspension-feeding in living brachiopods and bivalves: evolutionary implications. Paleobiology 19:32234

Samerotte AL, Drazen JC, Brand GL, Seibel BA, Yancy PH. 2007. Correlation of trimethylamine oxide and habitat depth within and among species of teleost fish: an analysis of causation. Physiol. Biochem. Zool. 80:197-208

Scher HD, Martin EE. 2006. Timing and climatic consequences of the opening of Drake Passage. Science 312:428-30

Seibel BA. 2007. On the depth and scale of metabolic rate variation: scaling of oxygen consumption rates and enzymatic activity in the Class Cephalopoda (Mollusca). 7. Exp. Biol. 210:1-11

Seibel BA, Drazen JC. 2007. The rate of metabolism in marine animals: environmental constraints, ecological demands and energetic opportunities. Philos. Trans. $R$. Soc. London Ser. B. In press. doi:10.1098/rstb.2007.2101 
Sepkoski JJ Jr. 1991. Diversity in the Phanerozoic oceans: a partisan view. In The Unity of Evolutionary Biology: Proc. 4th Int. Congr. Syst. Evol. Biol., Vol. 1, ed. EC Dudley, pp. 210-36. Portland, Oregon: Dioscorides Press

Smetacek V, Nicol S. 2005. Polar ocean ecosystems in a changing world. Nature 437:362-68

Snelgrove PVR. 2001. Marine sediments. In Encyclopedia of Biodiversity, ed. SA Levin, pp. 71-84. San Diego: Academic

Somero GN, De Vries AL. 1967. Temperature tolerance of some Antarctic fishes. Science 156:257-58

Stachowitz JJ, Terwin JR, Whitlatch RB, Osman RW. 2002. Linking climate change and biological invasions: ocean warming facilitates nonindigenous species invasions. Proc. Natl. Acad. Sci. USA 99:15497-500

Stanley SM. 1977. Trends, rates and patterns of evolution in the Bivalvia. In Patterns of Evolution as Illustrated by the Fossil Record, ed. A Hallam, pp. 209-50. Amsterdam: Elsevier

Stilwell JD, Zinsmeister WJ. 1992. Molluscan Systematics and Biostratigraphy: Lower Tertiary La Meseta Formation, Seymour Island, Antarctic Peninsula. Washington, DC: Am. Geophys. Union, Antarct. Res. Ser. 55, 192 pp.

Tavares M, De Melo GAS. 2004. Discovery of the first known benthic invasive species in the Southern Ocean: the North Atlantic spider crab Hyas araneus found in the Antarctic Peninsula. Antarct. Sci. 16:129-31

Thatje S. 2005. The future fate of the Antarctic marine biota? TREE 20:418-19

Thatje S, Anger K, Calcagno JA, Lovrich GA, Pörtner H-O, Arntz WE. 2005. Challenging the cold: crabs reconquer the Antarctic. Ecology 86:619-25

Thatje S, Arntz WE. 2004. Antarctic reptant decapods: more than a myth? Polar Biol. 27:195-201

Thatje S, Fuentes V. 2003. First record of anomuran and brachyuran larvae (Crustacea: Decapoda) from Antarctic waters. Polar Biol. 26:279-82

Thatje S, Lörz AN. 2005. First record of lithodid crabs from Antarctic waters off the Balleny Islands. Polar Biol. 28:334-37

Thatje S, Schnack-Schiel S, Arntz WE. 2003. Developmental trade-offs in Subantarctic meroplankton communities and the enigma of low decapod diversity at high southern latitudes. Mar. Ecol. Prog. Ser. 260:195-207

Thies D, Reif W-E. 1985. Phylogeny and evolutionary ecology of Mesozoic Neoselachii. N. Fb. Geol. Paläont., Abh. 169:333-61

Thorson G. 1950. Reproduction and larval ecology of marine bottom invertebrates. Biol. Rev. Camb. Philos. Soc. 25:1-45

Tripati A, Backman J, Elderfield H, Ferretti P. 2005. Eocene bipolar glaciation associated with global carbon cycle changes. Nature 436:341-46

Vermeij GJ. 1977. The Mesozoic marine revolution: evidence from snails, predators and grazers. Paleobiology 3:245-58

Vermeij GJ. 1978. Biogeography and Adaptation: Patterns of Marine Life. Cambridge, MA: Harvard Univ. Press. 332 pp.

Vermeij GJ. 1987. Evolution and Escalation: An Ecological History of Life. Princeton: Princeton Univ. Press. 527 pp. 
Wagner PJ, Kosnik MA, Lidgard S. 2006. Abundance distributions imply elevated complexity of post-Paleozoic marine ecosystems. Science 314:1289-92

Wakeling JW, Johnston IA. 1998. Muscle power output limits fast-start performance in fish. F. Exp. Biol. 201:1505-26

Walsh JJ. 1988. On the Nature of Continental Shelves. San Diego: Academic. 520 pp.

Walther G-R, Post E, Convey P, Menzel A, Parmesan C, et al. 2002. Ecological responses to recent climate change. Nature 416:389-95

Watling L, Thurston MH. 1989. Antarctica as an evolutionary incubator: evidence from the cladistic biogeography of the amphipod family Iphimediidae. In Origins and Evolution of the Antarctica Biota, ed. JA Crame, pp. 297-309. Bath, United Kingdom: Geol. Soc.

Werner JE, Blake DB, Aronson RB. 2004. Effects of late Eocene cooling on Antarctic marine communities. Boll. Geofis. 45(Suppl. 2):262-65 (Abstr.)

Wiedman LA, Feldmann RM. 1988. Brachiopoda from the La Meseta Formation (Eocene), Seymour Island, Antarctica. See Feldman \& Woodburne 1988, pp. 449-57

Woll AK, Burmeister AD. 2002. Occurrence of northern stone crab (Lithodes maja) at southeast Greenland. In Crabs in Cold-Water Regions: Biology, Management, and Economics, ed. AJ Paul, EG Dawe, R Elner, GS Jamieson, GH Kruse, et al. pp. 733-49. Fairbanks: Univ. Alaska Sea Grant Coll. Program, AK-SG-02-01

Zachos J, Pagani M, Sloan L, Thomas E, Billups K. 2001. Trends, rhythms, and aberrations in global climate $65 \mathrm{Ma}$ to present. Science 292:686-93

Zinsmeister WJ, Feldmann RM. 1984. Cenozoic high latitude heterochroneity of Southern Hemisphere marine faunas. Science 224:281-83

Zwally HJ, Comiso JC, Parkinson CL, Cavalieri DJ, Gloersen P. 2002. Variability of Antarctic sea ice 1979-1998. 7. Geophys. Res. 107:3041-59 


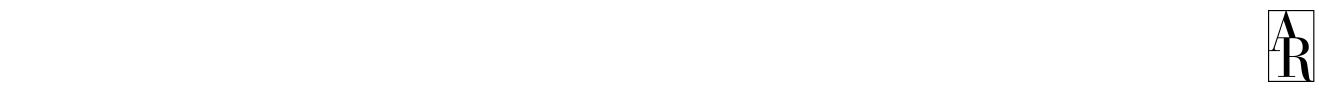

\section{Contents}

Annual Review of Ecology, Evolution, and Systematics

Evolution of Animal Photoperiodism

William E. Bradshaw and Christina M. Holzapfel ...

1

Virus Evolution: Insights from an Experimental Approach

Santiago F. Elena and Rafael Sanjuán

The Social Lives of Microbes

Stuart A. West, Stephen P. Diggle, Angus Buckling, Andy Gardner,

and Ashleigh S. Griffin

Sexual Selection and Speciation

Michael G. Ritchie

Kin Selection and the Evolutionary Theory of Aging

Andrew F.G. Bourke

Climate Change and Invasibility of the Antarctic Benthos

Richard B. Aronson, Sven Thatje, Andrew Clarke, Lloyd S. Peck,

Daniel B. Blake, Cheryl D. Wilga, and Brad A. Seibel ....

Spatiotemporal Dimensions of Visual Signals in Animal

Communication

Gil G. Rosenthal

Gliding and the Functional Origins of Flight: Biomechanical Novelty

or Necessity?

Robert Dudley, Greg Byrnes, Stephen P. Yanoviak,

Brendan Borrell, Rafe M. Brown, and Fimmy A. McGuire

How Mutational Networks Shape Evolution: Lessons from

RNA Models

Matthew C. Cowperthwaite and Lauren Ancel Meyers ....

How Does It Feel to Be Like a Rolling Stone? Ten Questions about

Dispersal Evolution

Ophélie Ronce

Exploring Cyanobacterial Mutualisms

Kayley M. Usher, Birgitta Bergman, and Fobn A. Raven 
Human Impacts in Pine Forests: Past, Present, and Future

David M. Richardson, Philip W. Rundel, Stephen T. Jackson,

Robert O. Teskey, James Aronson, Andrzej Bytnerowicz,

Michael 7. Wingfield, and Şerban Proches

Chemical Complexity and the Genetics of Aging

Scott D. Pletcher, Hadise Kabil, and Linda Partridge ....

A Global Review of the Distribution, Taxonomy, and Impacts of

Introduced Seaweeds

Susan L. Williams and Fennifer E. Smith

The Very Early Stages of Biological Evolution and the Nature of the

Last Common Ancestor of the Three Major Cell Domains Arturo Becerra, Luis Delaye, Sara Islas, and Antonio Lazcano.

Functional Versus Morphological Diversity in Macroevolution

Peter C. Wainwright

Evolutionary Game Theory and Adaptive Dynamics of

Continuous Traits

Brian 7. McGill and foel S. Brown

The Maintenance of Outcrossing in Predominantly Selfing Species:

Ideas and Evidence from Cleistogamous Species

Christopher G. Oakley, Ken S. Moriuchi, and Alice A. Winn ...

Sympatric Speciation: Models and Empirical Evidence

Daniel I. Bolnick and Benjamin M. Fitzpatrick ....

The Evolution of Color Polymorphism: Crypticity, Searching Images, and Apostatic Selection

Alan B. Bond

Point, Counterpoint: The Evolution of Pathogenic Viruses and their Human Hosts

Michael Worobey, Adam Bjork, and foel O. Wertheim

The Evolution of Resistance and Tolerance to Herbivores

Fuan Núñez-Farfán, Fuan Fornoni, and Pedro Luis Valverde

Plant-Animal Mutualistic Networks: The Architecture of Biodiversity

Fordi Bascompte and Pedro Fordano

Gene Flow and Local Adaptation in Trees

Outi Savolainen, Tanja Pybäjärvi, and Timo Knürr

The Evolution of Multicellularity: A Minor Major Transition?

Richard K. Grosberg and Richard R. Stratbmann ...

Developmental Genetics of Adaptation in Fishes: The Case for Novelty

7.T. Streelman, C.L. Peichel, and D.M. Parichy 
Terrestrial Carbon-Cycle Feedback to Climate Warming

Yiqi Luo

Shortcuts for Biodiversity Conservation Planning: The Effectiveness of Surrogates Ana S.L. Rodrigues and Thomas M. Brooks

Understanding the Effects of Marine Biodiversity on Communities and Ecosystems

Fohn 7. Stachowicz, Fohn F. Bruno, and 7. Emmett Duffy

Stochastic Dynamics of Plant-Water Interactions Gabriel Katul, Amilcare Porporato, and Ram Oren

Evolutionary Endocrinology: The Developing Synthesis between Endocrinology and Evolutionary Genetics Anthony 7. Zera, Lawrence G. Harshman, and Tony D. Williams

The Role of Behavior in the Evolution of Spiders, Silks, and Webs Fritz Vollrath and Paul Selden

Applications of Flow Cytometry to Evolutionary and Population Biology Paul Kron, Fan Suda, and Brian C. Husband

\section{Indexes}

Cumulative Index of Contributing Authors, Volumes 34-38 877

Cumulative Index of Chapter Titles, Volumes 34-38

\section{Errata}

An online log of corrections to Annual Review of Ecology, Evolution, and Systematics articles may be found at http://ecolsys.annualreviews.org/errata.shtml 